\title{
УСПАДКУВАННЯ ОЗНАК СТАТІ У САМОЗАПИЛЕНИХ ЛІНІЙ ОДНОДОМНИХ КОНОПЕЛЬ ТА ЇЇ ЕВОЛЮЦИЙНІ АСПЕКТИ
}

\section{С. В. Міщенко}

Дослідна станція луб'яних культур Інституту сільського господарства Північного Сходу НААН

На основі аналізу літературних джерел наведено аргументи на користь концепції еволюції статі конопель у напрямку гермафродитизм $\rightarrow$ однодомність $\rightarrow$ дводомність. Подано результати вивчення особливостей успадкування ознак статі в $\mathrm{I}_{1}-\mathrm{I}_{4}$ рослин однодомної фемінізованої матірки сортів середньоросійського (Глухівські 58, Глесія) і південного (Золотоніські 15) типу конопель.

Коноплі посівні, стать, однодомність, успадкування, однодомна фемінізована матірка, самозапилена лінія, селекиія, еволюиія

Протягом усього часу вирощування однодомних конопель (Cannabis sativa L.) існує проблема закріплення ознаки однодомності, оскільки сорти схильні до спонтанного вищеплення плосконі, зростаюча кількість якої може поступово розмити межу між однодомними і дводомними коноплями.

За Е. Л. Кордюм, Г. И. Глущенко еволюційний розвиток статі рослин може здійснюватися двома шляхами: дводомні рослини виникають від гермафродитних через проміжну однодомну форму або безпосередньо від гермафродитів [1]. М. Д. Мигаль вважає, що явище статевого поліморфізму конопель, яке виражається в наявності дводомних рослин, статевих типів однодомних конопель $з$ фемінізованим і маскулінізованим габітусом та різним співвідношенням чоловічих і жіночих квіток у суцвітті, а також різних форм інтерсексуальності, є прямим відображенням особливостей онтогенетичного й філогенетичного розвитку [2]. Н. Н. Гришко вказує на те, що коноплі пройшли такий історичний шлях розвитку статі: гермафродитні рослини $\rightarrow$ однодомні рослини $\rightarrow$ дводомні рослини [3].

Концепція еволюції статі конопель у зазначеному напрямку доводиться М. Д. Мигалем такими основними аргументами: 1) відсутністю потенційно двостатевих жіночих і чоловічих квіток у дводомних конопель; 2) відсутністю нормально розвинених гермафродитних квіток; 3) вищим ступенем життєздатності матірки й плосконі порівняно 3 однодомними

(C) С. В. Міщенко. 2013.

ISSN 0582-5075. Селекція і насінництво. 2013. Випуск 103. 
рослинами; 4) наявністю генетично обумовленого ряду статевих типів, який показує поступовий перехід однодомних рослин до дводомних $[2,4,5]$. Частково до них ми додали б ще й такі: 1) відсутність самостерильності у однодомних рослин конопель [6]; 2) наявність реліктових нектарників у квітках конопель як анемофілів [7]; 3) легкість трансформації однодомних конопель у дводомні при вільному перезапиленні. Розглянемо ці аргументи.

У природі має місце досить чітке розмежування двох типів одностатевих квіток: 1) квітки без зачатків (рудиментів) органів іншої статі - структурно одностатеві квітки; такі чоловічі і жіночі квітки описані у однодомних видів Betula L., Spinacia oleracea L., Salix caprea L., Populus pyramidalis Rozier, жіночі - у дводомного виду Urtica diodica L. та ін.; 2) квітки із зачатками (рудиментами) органів іншої статі, ступінь розвитку яких може варіювати, - потенційно двостатеві квітки; такі чоловічі і жіночі квітки описані в однодомних видів Zea mays L., Acer L., чоловічі - у дводомного виду Urtica diodica L. і однодомного Aesculus hippocastanum L., жіночі - у Laurus nobilis L. та ін. [1]. У конопель наявна виключно перша група квіток [1].

М. Д. Мигаль вказує, що порушення в розвитку квіток конопель зустрічаються часто. У результаті зміни статі генеративних органів, як правило, утворюються двостатеві квітки з недорозвиненим андроцеєм і гінецеєм. Такі квітки прийнято називати інтерсексуальними. Автор не зустрічав в природі справжніх гермафродитних квіток 3 нормально розвиненими генеративними органами обох статей. Він стверджує, що так звані “гермафродити", - це не що інше, як інтерсексуальні рослини, тобто особини 3 аномальними двостатевими квітками [2]. Найбільш поширеною формою порушень у розвитку квіток конопель $\epsilon$ онтогенетична інтерсексуальність однодомних рослин. Чоловічі квітки в суцвітті однодомних особин змінюються жіночими не різко, а шляхом поступового перетворення андроцея в гінецей. Перетворення чоловічих квіток у жіночі схематично проходить у такій послідовності: нормальні чоловічі квітки (андроцей), чоловічі квітки з порушеннями без ознак інтерсексуальності, андрогіноморфні квітки (інтерсексуальні квітки 3 перевагою ознак андроцея), гінандроморфні квітки (інтерсексуальні квітки з перевагою ознак гінецея), нормальні жіночі квітки (гінецей). Також у популяції дводомних і однодомних конопель зустрічаються інтерсексуальні рослини - індивіди, в яких замість усіх або частини чоловічих квіток утворюються двостатеві тератологічні квітки (модифікаційна інтерсексуальність рослин дводомних і однодомних конопель). У суцвітті цих індивідів зустрічаються п'ять типів квіток: нормальні чоловічі, нормальні жіночі, інтерсексуальні, тератологічні чоловічі та тератологічні жіночі без ознак перетворення статі. Описана інтерсексуальна форма карликових рослин та спадкова форма інтерсексуальної чоловічої стерильності однодомних конопель $[2,5,8]$. 
Спільним для усіх форм інтерсексуальності конопель $\epsilon$ те, що трансформація ознак статі в природних умовах проходить у напрямку від чоловічих до жіночих генеративних органів [2], хоча $\epsilon$ дані про маскулінізацію жіночих квіток [1].

Вищий ступінь життєздатності матірки й плосконі порівняно 3 однодомними рослинами полягає у наступному. Чоловічі квітки плосконі, маючи довгі квітконіжки, розташовуються на квітконосних пагонах розріджено, що створює умови для вільного розкриття квіток, легкого звільнення пиляків від пилку й осипання їх після відцвітання, порівняно 3 однодомними рослинами плоскінь цвіте інтенсивніше й дає більшу масу пилку в середньому 3 рослини, пилок більш конкурентоздатний до запилення; вищі показники маси тисячі насінин та їх схожості у матірки порівняно з рослинами однодомних конопель тощо $[2,5]$.

Як вказують Е. Л. Кордюм, Г. И. Глущенко, різноманітні статеві форми зустрічаються у родинах і порядках, які займають різне місце в системі. Причому, якщо для одних таксономічних груп, зокрема родин чи родів, характерна якась одна статева форма, то для інших - різноманітні поєднання декількох статевих форм, що може спостерігатись і в межах одного виду (Plantago media L., Ceratonia siliqua L., Carica papaya L.) [1].

У природних умовах коноплі є дводомним видом з чітко вираженим статевим диморфізмом. Жіночі рослини (матірка) мають компактне суцвіття й жіночі квітки, чоловічі рослини (плоскінь) мають розріджене суцвіття й чоловічі квітки. 3 біологічної точки зору розрив у дозріванні плосконі і матірки є адаптацією до умов існування, а дводомні коноплі - сучасний етап еволюційного розвитку виду. 3 практичного боку більш раннє достигання чоловічих рослин (приблизно на місяць) викликає труднощі при збиранні врожаю. Ось чому вчені зосередили свої зусилля на створенні одночасно дозріваючих конопель, які згодом були створені.

Згідно сучасної класифікації $[2,5]$, в основу якої покладені ознаки габітусу рослини і співвідношення чоловічих та жіночих квіток у суцвітті, статеві типи однодомних конопель об'єднані у фемінізовану (з компактним суцвіттям) та маскулінізовану (з розрідженим суцвіттям) групи. До фемінізованої групи належать: матірка однодомних конопель (МОК) - усі квітки жіночі, однодомна фемінізована матірка (ОФМ) - жіночі квітки переважають, справжні однодомні фемінізовані рослини (СОФР) приблизно однакове співвідношення жіночих і чоловічих квіток, однодомна фемінізована плоскінь (ОФП) - чоловічі квітки переважають, фемінізована плоскінь (ФП) - усі квітки чоловічі. Відповідно до маскулінізованої групи належать: маскулінізована матірка (MM), однодомна маскулінізована матірка (ОММ), справжні однодомні маскулінізовані рослини (СОМР), однодомна маскулінізована плоскінь (ОМП), плоскінь однодомних конопель (ПОК) $[2,5]$. За теорією генотипового визначення статі конопель 
$[2,5]$ явище множинного алелізму генів статі статевих хромосом $\epsilon$ причиною поліморфізму рослин однодомних конопель за первинними й вторинними ознаками статі. Об'єднання алелів IM з будь-якими алелями однодомності дає плоскінь, гетерозиготну за ознаками чоловічої й однодомної статі. Унаслідок комбінації між собою різних алелів однодомності, а також сполучення їх 3 алелями IF утворюється безперервний ряд рослин за габітусом від компактного типу матірки до розрідженого типу плосконі з різним співвідношенням чоловічих $\mathrm{i}$ жіночих квіток на них у залежності від валентності генетичних факторів аутосом комплексу AG, що сполучаються в процесі запліднення.

Г. С. Степанов вважає, що на певному етапі еволюції двостатева квітка ставала обмежуючим фактором еволюції, і нові умови середовища почали вимагати удосконалення іiі функцій шляхом переходу від гермафродитної статевої організації до роздільностатевої. При цьому жіноча квітка могла виникнути в результаті стерилізації андроцея двостатевої квітки, чоловіча - шляхом стерилізації гінецея. Ізоляція і відбір могли привести до корінної зміни сексуального типу рослин, тобто до вироблення екзогенного типу онтогенезу за ознакою статі, що на морфологічному рівні знайшло вираз в неоднаковому розміщенні квіток різних статевих типів на окремих особинах. Для конопель еволюційно простіше було перейти від самонесумісного гермафродитизму до однодомності, ніж виробити ефективний механізм самостерильності. Така точка зору підтверджується тим, що однодомні рослини майже ніколи не бувають самостерильними [6].

К. Фегри і Л. ван дер Пэйл вказують, що наявність реліктових нектарників у квітках анемофілів (у т. ч. й конопель), специфічні запахи свідчать про виникнення анемофілії від ентомофілії, яка характерна для гермафродитних рослин. $\mathrm{y}$ анемофілів розвиток йшов від роздільностатевості до дводомності, яка завжди $\epsilon$ вторинною у покритонасінних [7].

Вивчення співвідношення статевих типів у потомстві, отриманому від самозапилення рослин, особливо однодомної фемінізованої матірки, свідчать про значне розщеплення за ознакою статі та появу плосконі однодомних конопель - прямого дестабілізатора однодомності.

Так, K. Hirata акцентував увагу на дослідженні статевого складу першого покоління, отриманого від самозапилення індивідуальних однодомних рослин, названих автором інтерсексами, що спонтанно іноді вищеплюються у посівах дводомних форм. У $\mathrm{I}_{1}$ було отримано 78 рослин матірки, 45 - однодомних і 3 - плосконі (всього проаналізовано 126 особин) [9]. W. Hoffmann вказує, що у різних інцухт-сімей першого покоління вміст матірки коливається у межах $0-41,0 \%$, фемінізованих однодомних рослин 28,6-60,1 \%, фемінізованої плосконі - 16,3-71,4 \%, маскулінізованих 
статевих типів - 0-3,9 \% і плосконі - 0-7,0 \% [10]. За даними Н. Д. Мигаля у середньому вищеплюється 7,01 \% матірки однодомних конопель, 34,36 \% однодомної фемінізованої матірки, 35,44 \% справжніх однодомних фемінізованих рослин, 11,11 \% однодомної фемінізованої плосконі, 8,6 \% фемінізованої плосконі, 1,87 \% маскулінізованих статевих типів і 1,66 \% плосконі однодомних конопель. У іншому досліді - 3,50 \% матірки, 88,18 \% фемінізованих статевих типів однодомних конопель, $2,77 \%$ маскулінізованих статевих типів однодомних конопель і 5,55 \% плосконі у $\mathrm{I}_{1}$ сорту ЮСО-14 і 6,98 \%, 72,25\%, 2,43 і 17,74\% відповідно у $\mathrm{I}_{1}$ рослин гібрида ЮСО-14 / ЮСО-16 [5, 11].

Актуальність повторних досліджень статевої структури викликана наявністю селекційного матеріалу чи не вперше у світовій практиці 3 абсолютно високою стабільністю ознаки однодомності. Мета наших досліджень - встановити особливості успадкування ознак статі конопель в $\mathrm{I}_{1}-\mathrm{I}_{4}$ рослин ОФМ сортів різних еколого-географічних типів.

Дослідження проводили у 2008-2012 рр. на базі Дослідної станції луб'яних культур. Самозапилення рослин сортів середньоросійського (Глухівські 58 (Вікторія), Глесія) і південного (Золотоніські 15) типів проводили під індивідуальними ізоляторами 3 агроволокна в умовах вегетаційного будинку. Наступного року проводили аналіз потомства в розсаднику оцінки 3 площею живлення 30 х 5 см. Статеві типи визначали за відомою класифікацією $[2,5]$.

Якщо генотип ОФМ за факторами аутосом AaGG, алелі генів статі статевих хромосом з низькими ступенями $\left(\mathrm{i}_{\mathrm{m}} \mathrm{I}_{\mathrm{m}} \mathrm{F}_{\mathrm{m}} \mathrm{M}_{\mathrm{m}}\right)$, маємо отримати у $\mathrm{I}_{1}$ такий розподіл генотипів і фенотипів: 1 AAGG : 2 AaGG : 1 aaGG i відповідно 1 СОФР : 2 ОФМ : 1 МОК. Однак, у $\mathrm{I}_{1}$ Глухівські 58 за багаторічними даними у середньому вищепилося 7,3 \% МОК, 77,5 \% ОФМ, $8,8 \%$ СОФР (табл. 1). Аналогічно в $\mathrm{I}_{1}$ Глесія у середньому отримано $1,0 \%$ МОК, 89,1 \% ОФМ і 6,3 \% СОФР, у межах сімей ці показники становлять 0$9,1 \%, 60,0-100,0 \%$ і 0-22,7\% відповідно. Спостерігається зміщення ознак статі у бік жіночої.

Аналізуючи перше покоління від самозапилення, ми вже зазначали, що таке явище пов'язане з високим рівнем домінантності генів-реалізаторів жіночої статі з серії множинних алелів чи порівняно високою валентністю фактору G. На користь цього припущення спостерігається менша кількість СОФР порівняно з МОК $[12,13]$.

М. Д. Мигаль вказує, що потомки самозапиленої ОФМ посилюють ознаки жіночої статі, вищеплюють найбільшу кількість матірки як наслідок кумулятивної (сумісної) взаємодії однозначних за статтю генетичних факторів - алелів статевих хромосом 3 низькими ступенями, які контролюють компактний тип суцвіття, i аутосомного фактора G високої валентності $[2,5] .$. 
Таблиця 1

Успадкування ознак статі у самозапилених ліній сортів конопель середньоросійського типу, 2009-2012 рр.

\begin{tabular}{|c|c|c|c|c|c|c|c|c|c|}
\hline \multirow{2}{*}{$\begin{array}{c}\text { Сорт, } \\
\text { інцухт-покоління }\end{array}$} & \multirow{2}{*}{$\begin{array}{c}\text { Кількість } \\
\text { рослин, } \\
\text { шт. }\end{array}$} & \multirow{2}{*}{ Показник } & \multicolumn{7}{|c|}{ Співвідношення статевих типів, \% } \\
\hline & & & MOK & ОФМ & СОФР & ОФП & ФП & OMP & ПОК \\
\hline Гляна, стандарт & 716 & $\bar{x}$ & 0 & 90,9 & 5,6 & 2,8 & 0,7 & 0 & 0 \\
\hline $\begin{array}{l}\text { Глухівські 58, } \\
\text { популяція }\end{array}$ & 671 & $\bar{x}$ & 0 & 87,3 & 10,3 & 1,9 & 0,4 & 0 & 0,1 \\
\hline \multirow{2}{*}{$\begin{array}{l}\text { Глухівські 58, } \\
\text { вихідні форми }\end{array}$} & \multirow{2}{*}{817} & $\bar{x}$ & 0 & 89,6 & 7,1 & 3,1 & 0,2 & 0 & 0 \\
\hline & & Min-Max & - & $67,9-100,0$ & $0-28,6$ & $0-10,7$ & $0-2,6$ & - & - \\
\hline \multirow{2}{*}{$\mathrm{I}_{1}$ Глухівські 58} & \multirow{2}{*}{2344} & $\bar{x}$ & 7,3 & 77,5 & 8,8 & 3,9 & 0,3 & 0,0 & 2,2 \\
\hline & & Min-Max & $0-34,3$ & $45,0-100,0$ & $0-35,9$ & $0-19,0$ & $0-7,8$ & $0-2,2$ & $0-15,0$ \\
\hline \multirow{2}{*}{$\mathrm{I}_{2}$ Глухівські 58} & \multirow{2}{*}{795} & $\bar{x}$ & 3,4 & 84,0 & 9,6 & 2,4 & 0 & 0 & 0,6 \\
\hline & & Min-Max & $0-18,9$ & $40,0-100,0$ & $0-56,0$ & $0-15,4$ & - & - & $0-10,0$ \\
\hline \multirow{2}{*}{$\mathrm{I}_{3}$ Глухівські 58} & \multirow{2}{*}{555} & $\bar{x}$ & 1,4 & 87,0 & 8,6 & 2,8 & 0 & 0 & 0,2 \\
\hline & & Min-Max & $0-5,1$ & $70,0-100,0$ & $0-7,6$ & $0-11,7$ & - & - & $0-2,6$ \\
\hline \multirow{2}{*}{$\mathrm{I}_{4}$ Глухівські 58} & \multirow{2}{*}{126} & $\bar{x}$ & 0 & 89,7 & 9,5 & 0,8 & 0 & 0 & 0 \\
\hline & & Min-Max & - & $66,7-100,0$ & $0-30,0$ & $0-3,3$ & - & - & - \\
\hline Глесія, популяція & 283 & $\bar{x}$ & 0 & 96,2 & 3,8 & 0 & 0 & 0 & 0 \\
\hline \multirow{2}{*}{$\begin{array}{l}\text { Глесія, вихідні } \\
\text { форми }\end{array}$} & \multirow[t]{2}{*}{312} & $\bar{x}$ & 0 & 97,3 & 2,7 & 0 & 0 & 0 & 0 \\
\hline & & Min-Max & - & $94,1-100,0$ & $0-5,9$ & - & - & - & - \\
\hline \multirow{2}{*}{$\mathrm{I}_{1}$ Глесія } & \multirow[t]{2}{*}{488} & $\bar{x}$ & 1,0 & 89,1 & 6,3 & 2,3 & 0,8 & 0 & 0,5 \\
\hline & & Min-Max & $0-9,1$ & $60,0-100,0$ & $0-22,7$ & $0-15,4$ & $0-10,0$ & - & $0-7,1$ \\
\hline \multirow{2}{*}{$\mathrm{I}_{2}$ Глесія } & \multirow[t]{2}{*}{124} & $\bar{x}$ & 0 & 95,2 & 4,8 & 0 & 0 & 0 & 0 \\
\hline & & Min-Max & - & $73,3-100,0$ & $0-26,7$ & - & - & - & - \\
\hline
\end{tabular}


У цілому ж отримано досить високий вміст ОФМ, особливо у першому і другому поколіннях від самозапилення рослин сорту Глесія $(89,1 \%$ і 95,2 \%), що є позитивним моментом для селекції. Певною мірою можна стверджувати у широкому розумінні про значну гомозиготацію рецесивних ознак статі у популяції сучасних сортів конопель. У 2011 р. у семи з 14 проаналізованих сімей (тобто у 50 \% сімей) $\mathrm{I}_{1}$ Глесія при вибірці 12-42 рослини обліковано $100,0 \%$ даного статевого типу при найменшому значенні показника $69,2 \%$, а ПОК вищепилося в середньому 0,3\% - це одна рослина лише в одній сім'ї при вибірці 12-44 рослин. У 2012 р. у двох 3 п'яти досліджуваних сімей (тобто у $40 \%$ сімей) при вибірці 17-27 особини обліковано 100,0 \% ОФМ при найменшому значенні показника $60,0 \%$. ПОК вищепилося в середньому $0,8 \%$ - це одна рослина лише в одній сім'ї при вибірці 17-36, що $\epsilon$ найкращим показником серед досліджуваних сортів.

Подібні результати отримані і по $\mathrm{I}_{1}$ Золотоніські 15 (табл. 2), але в цьому випадку спостерігається більша кількість у потомстві таких статевих типів, як СОФР (у середньому 16,4\%), ОФП (11,4\%), ОМР $(0,4 \%)$ та істотно менша кількість ОФМ (63,7 \%), що пов'язуємо зі статевими особливостями сорту південного типу (потрібно провести аналогію із співвідношенням статевих типів у вихідній формі).

Слід підкреслити, що в результаті самозапилення вищеплюються статеві типи, які були відсутні безпосередньо у вихідних форм та популяціях відповідних сортів. До таких статевих типів належать еволюційно прогресивні форми - МОК та ПОК, які є небажаними 3 господарської точки зору.

При подальшому самозапиленні $\mathrm{I}_{1}$ до $\mathrm{I}_{2}-\mathrm{I}_{4}$ у потомстві поступово зменшується вміст МОК і ПОК (останнього статевого типу з 2,2 \% до 0 \% у самозапилених ліній сорту Глухівські 58, з 0,5 \% до 0 \% у самозапилених ліній сорту Глесія і з $1,9 \%$ до $0 \%$ у самозапилених ліній сорту Золотоніські 15), а збільшується кількість ОФМ (з 77,5 \% до 89,7 \%, з 89,1 \% до 95,2 \% і 3 63,7 \% до 96,8 \% відповідно). Також зменшується кількість ФП і ОМР, що доволі $є$ позитивним, а вміст СОФР і ОФП коливається у бік збільшення чи зменшення.

Статевий склад $\mathrm{I}_{4}$ Глухівські 58 - 89,7 \% ОФМ, 9,5\% СОФР, 0,8\% ОФП, $\mathrm{I}_{2}$ Глесія - 95,2 \% ОФМ, 4,8 \% СОФР, $\mathrm{I}_{4}$ Золотоніські 15 - 96,8\% ОФМ, 2,9 \% СОФР, 0,3 \% ОФП. Таким чином, підтверджено, що інцухтметод у певній мірі може стабілізувати ознаки однодомності.

Позитивним для селекції $\epsilon$ i те, що можна виділити цінні самозапилені лінії і почати добір з $\mathrm{I}_{1}$ саме за ознакою відсутності прямого дестабілізатора однодомності ПОК й таких, що складаються повністю 3 основного статевого типу ОФМ. Відсоток таких сімей подано на рисунках 1,2 . 

Таблиця 2

Успадкування ознак статі у самозапилених ліній сорту конопель південного типу, 2009-2012 рр.

\begin{tabular}{|c|c|c|c|c|c|c|c|c|c|}
\hline \multirow{2}{*}{$\begin{array}{c}\text { Сорт, інцухт- } \\
\text { покоління }\end{array}$} & \multirow{2}{*}{$\begin{array}{c}\text { Кількість } \\
\text { рослин, шт. }\end{array}$} & \multirow{2}{*}{ Показник } & \multicolumn{7}{|c|}{ Співвідношення статевих типів, \% } \\
\hline & & & MOK & ОФМ & СОФР & ОФП & $\Phi \Pi$ & OMP & ПОК \\
\hline $\begin{array}{l}\text { Золотоніські 15, } \\
\text { популяція }\end{array}$ & 591 & $\bar{x}$ & 0 & 78,3 & 9,7 & 10,0 & 1,6 & 0 & 0,4 \\
\hline \multirow{2}{*}{$\begin{array}{l}\text { Золотоніські 15, } \\
\text { вихідні форми }\end{array}$} & \multirow[b]{2}{*}{747} & $\bar{x}$ & 0 & 76,6 & 12,9 & 9,7 & 0,8 & 0 & 0 \\
\hline & & Min-Max & - & $\begin{array}{c}27,3- \\
94,1 \\
\end{array}$ & $\begin{array}{c}0- \\
57,6 \\
\end{array}$ & $\begin{array}{c}0- \\
27,6 \\
\end{array}$ & $\begin{array}{l}0- \\
4,4\end{array}$ & - & - \\
\hline \multirow[b]{2}{*}{$\mathrm{I}_{1}$ Золотоніські 15} & \multirow[b]{2}{*}{1297} & $\bar{x}$ & 5,8 & 63,7 & 16,4 & 11,4 & 0,4 & 0,4 & 1,9 \\
\hline & & Min-Max & $\begin{array}{c}0- \\
41,7 \\
\end{array}$ & $\begin{array}{l}10,0- \\
100,0\end{array}$ & $\begin{array}{c}0- \\
60,0\end{array}$ & $\begin{array}{c}0- \\
60,0\end{array}$ & $\begin{array}{l}0- \\
7,1\end{array}$ & $\begin{array}{c}0- \\
10,9\end{array}$ & $\begin{array}{c}0- \\
15,8 \\
\end{array}$ \\
\hline \multirow[b]{2}{*}{$\mathrm{I}_{2}$ Золотоніські 15} & \multirow[b]{2}{*}{612} & $\bar{x}$ & 2,5 & 75,7 & 16,0 & 4,6 & 0,7 & 0,3 & 0,2 \\
\hline & & Min-Max & $\begin{array}{c}0- \\
12,5 \\
\end{array}$ & $\begin{array}{l}16,7- \\
100,0\end{array}$ & $\begin{array}{c}0- \\
50,0 \\
\end{array}$ & $\begin{array}{c}0- \\
41,7 \\
\end{array}$ & $\begin{array}{c}0- \\
13,3 \\
\end{array}$ & $\begin{array}{c}0- \\
15,8 \\
\end{array}$ & $\begin{array}{l}0- \\
5,6 \\
\end{array}$ \\
\hline \multirow[b]{2}{*}{$\mathrm{I}_{3}$ Золотоніські 15} & \multirow[b]{2}{*}{124} & $\bar{x}$ & 0 & 96,8 & 3,2 & 0 & 0 & 0 & 0 \\
\hline & & Min-Max & - & $\begin{array}{l}92,6- \\
100,0 \\
\end{array}$ & $\begin{array}{l}0- \\
7,4\end{array}$ & - & - & - & - \\
\hline \multirow[b]{2}{*}{$\mathrm{I}_{4}$ Золотоніські 15} & \multirow[b]{2}{*}{340} & $\bar{x}$ & 0 & 96,8 & 2,9 & 0,3 & 0 & 0 & 0 \\
\hline & & Min-Max & - & - & - & - & - & - & - \\
\hline
\end{tabular}




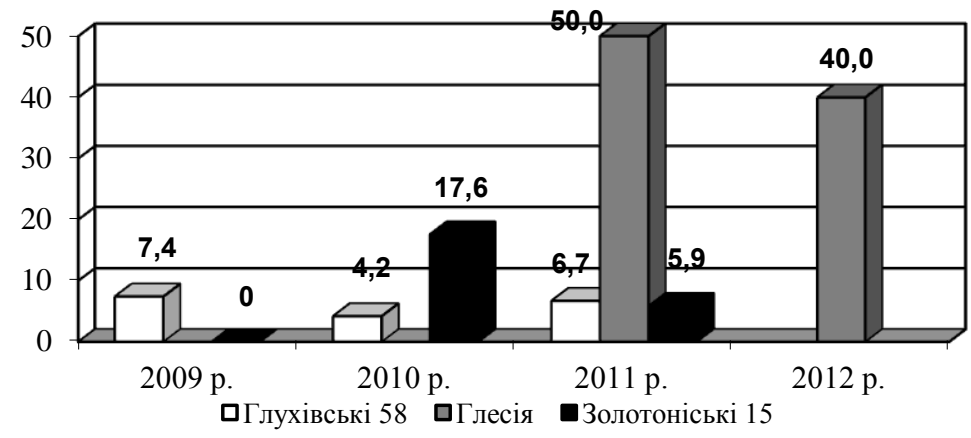

Рис. 1 Частка сімей самозапилених ліній, які складаються виключно 3 ОФМ, \%

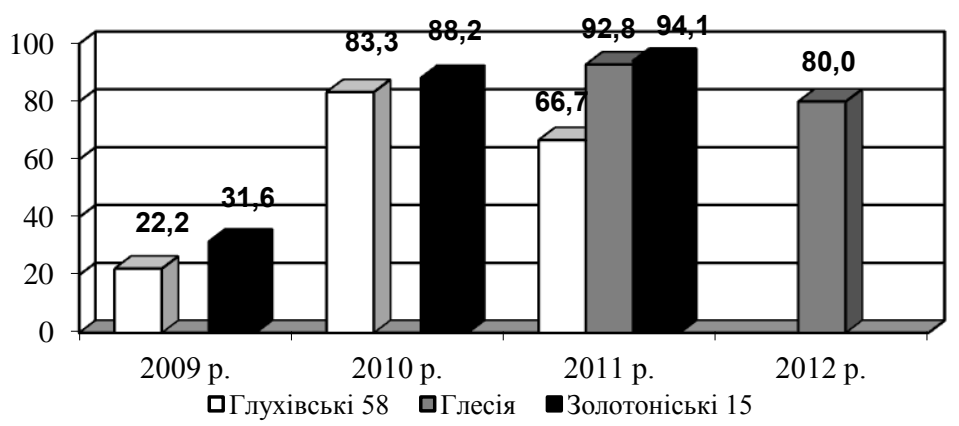

Рис. 2 Частка сімей самозапилених ліній з відсутністю ПОК, \%

Висновки. 1. У результаті самозапилення ОФМ сортів Глухівські 58, Глесія, Золотоніські 15 спостерігається зміщення статевої структури у бік жіночої статі та вищеплення еволюційно прогресивних форм - МОК і ПОК, які є небажаними з господарської точки зору.

2. Отримано досить високий вміст ОФМ (особливо у самозапилених ліній сорту Глесія), що є позитивним для селекції. Показано можливість добору цінних самозапилених ліній за ознакою відсутності прямого дестабілізатора однодомності ПОК та за 100 \%-им вмістом ОФМ.

3. При подальшому самозапиленні $\mathrm{I}_{1}$ до $\mathrm{I}_{2}-\mathrm{I}_{4}$ у потомстві поступово зменшується вміст МОК і ПОК (останнього статевого типу з 2,2 \% до $0 \%$, 3 $0,5 \%$ до $0 \%$ і з $1,9 \%$ до $0 \%$ відповідно у самозапилених ліній сортів Глухівські 58, Глесія і Золотоніські 15), а збільшується кількість ОФМ (3 77,5 \% до 89,7 \%, з 89,1 \% до 95,2 \% і з 63,7 \% до 96,8 \% відповідно).

4. Потомства самозапилених рослин сортів середньоросійського типу відмінні від південного за статевою структурою, яка у певній мірі зщалежить від еколого-географічних особливостей. 


\section{Список використаних джерел}

1. Кордюм E. Л. Цитоэмбриологические аспекты проблемы пола покрытосеменных / Е. Л. Кордюм, Г. И. Глущенко. - К. : Наукова думка, 1976. - $198 \mathrm{c}$.

2. Мигаль М. Д. Експериментальна зміна статі конопель : [монографія] / М. Д. Мигаль. - Суми : СОД, Козацький вал, 2004. - 248 с.

3. Биология конопли : [Труды ВНИИ конопли / под ред. Н. Н. Гришко]. К.-Харків : Держсільгоспвид УРСР, 1935. - Вып. 8. - 272 с.

4. Мигаль Н. Д. Генетические аспекты эволюции пола конопли / Н. Д. Мигаль // Генетика. - 1991. - Т. 27, № 5. - С. 1561-1569.

5. Мигаль Н. Д. Генетика пола конопли : [монография] / Н. Д. Мигаль. Глухов : 1992. $-212 \mathrm{c.}$

6. Степанов Г. С. Разнокачественность репродуктивных органов у основных половых типов однодомной конопли / Г. С. Степанов // Доклады Россельхозакадемии. - 1997. - № 6. - С. 12-14.

7. Фегри К. Основы экологии опыления / Фегри К., Л. ван дер Пэйл ; пер. с англ. Л. В. Ковалевой, Э. Л. Миляевой ; под. ред. А. П. Меликяна. - М. : Мир, 1982. - 380c.

8. Бородина Е. И. Цитоэмбриология интерсексуальности половых типов конопли : дисс. ... кандидата с.-г. наук : 06.00.23 / Бородина Екатерина Ивановна. - Глухов, 1995. - 139 с.

9. Hirata K. Sex determination in hemp (Cannabis sativa L.) / K. Hirata // Genetics. - 1927. - V. 19, № 1. - P. 65-79.

10. Hoffmann W. Die Vererbung der Geschlechtsformen des Hanfes (Cannabis sativa L.) / W. Hoffman // Der Züchter. - 1947. - B. 17-18, № 9. - S. 257-277.

11. Мигаль Н. Д. Гомозиготация признака однодомности конопли инцухтметодом / Н. Д. Мигаль // Технология возделывания и обработки конопли : сб. научн. трудов. - Глухов, 1991. - С. 7-13.

12. Міменко $C$. B. Успадкування ознак статі в першому поколінні самозапилених рослин середньоросійського i південного сортів однодомних конопель / С. В. Міщенко, І. М. Лайко // Вісник Сумського національного аграрного університету. - 2011. - Вип. 4 (21). - С. 161163. - (Серія “Агрономія і біологія").

13. Міменко C. В. Посилення прояву ознак жіночої статі конопель у потомстві самозапилених рослин однодомної фемінізованої матірки / С. В. Міщенко, I. М. Лайко // Фактори експериментальної еволюції організмів : зб. наук. праць / гол. ред. В. А. Кунах. - К. : Логос, 2011. T. 10. - C. 481-486. 